\title{
Evaluation of Anti-Rheumatoid Arthritis Activity of White, Black Mulberry and Turmeric in Complete Freund's Adjuvant Induced Rheumatoid Arthritis Rats
}

\author{
SAHAR O. EL-SHAFAI, Ph.D.; EMAD M.A. EL-KHOLIE, Ph.D. and FATMA M.H. ABO EL-NOR, M.Sc. \\ The Department of Nutrition \& Food Science, Faculty of Home Economics, Menufia University
}

\begin{abstract}
Background: Rheumatoid arthritis (RA) is an autoimmune disorder which affects $0.5-1 \%$ of the adult population. RA affects any age group, including children, but is mostly diagnosed between the ages of 40-55 years.

Aim of Study: The aim of this investigation is to evaluate of anti-rheumatoid arthritis activity of white mulberry, black mulberry and turmeric in complete freund's adjuvant induced rheumatoid arthritis rats.
\end{abstract}

Materials and Methods: A total of 40 male albino rats weighing $(140 \pm 10 \mathrm{~g})$ were used in this study. Rats were divided into 8 group, first group fed on basal diet as a control negative group, the second group were injected by $0.1 \mathrm{ml}$ of complete fruend's adjuvant and used as a positive control group , while the other groups were fed on basal diets blended with $5-10 \%$ of the white mulberry, black mulberry, turmeric as powder for 28 days.

Results: The results showed that turmeric, black mulberry and white mulberry record the better results in Erythrocyte Sedimentation Rate (ESR), and C reactive protein (CRP) at entry, Rheumatoid factor (RF), Anti cyclic citrullinated peptide (Anti-CCP) because of its anti-cancer, anti-inflammatory, anti-diabetic, and anti-rheumatic properties associated with good tolerability and safety.

Conclusion: The study recommends the tested medicinal plants are useful for healing as well as for curing of human diseases because of the presence of phytochemical constituents.

Key Words: Rheumatoid arthritis - Complete Freund's Adjuvant-Anti-inflammatory - The medicinal plants and Mulberry.

\section{Introduction}

RHEUMATOID arthritis (RA) is a chronic inflammatory disease manifesting itself in various extra-articular signs and progressive articular dam-

Correspondence to: Dr. Sahar O. El-Shafai,

The Department of Nutrition \& Food Science,

Faculty of Home Economics, Menufia University age RA is an autoimmune disorder which affects $0.5-1 \%$ of the adult population [1]

More women than men are affected (ratios of between 2:1 to 5:1 have been reported) and RA affects any age group, including children, but is mostly diagnosed between the ages of $40-55$ years, recent research indicates that. African blacks may have a younger age of onset than is the norm in western communities [2].

In 1987, identified the American Society of rheumatic symptoms for seven Romatoydder in or to be diagnosed with rheumatoid arthritis that the top four of whom have found before for 6 weeks, these symptoms are: Morning stiffness, Arthritis of 3 or more joint, Arthritis of hand joints, Symmetric arthritis, Rheumatoid nodules, Radiographic changes [3].

Rheumatoid arthritis can be difficult to diagnose in its early stages. Doctors have to arrive at diagnosis based on your symptoms, a physical examination and the results of variety of X-rays, scans and blood test, Blood tests include: Erythrocyte sedimentation rate (ESR), and $\mathrm{C}$ reactive protein (CRP) at entry, Rheumatoid factor (RF), Anti cyclic citrullinated peptide [4].

Freund's complete adjuvant is used to induce arthritis in animals and shows several clinical and histological similarities to human RA. In the present study, a single injection of Freund's complete adjuvant at the subplantar surface was capable of producing pronounced arthritis in the paws and ankles of animals [5]. Freund's complete adjuvant (F CA) (a suspension of heat-killed Mycobacterium tuberculosis in mineral oil; Sigma Aldrich, USA) [6] 
Berries represent a variety of small fruits characterized by the red, purple, and blue color. The most common berries are: Blueberry, bilberry, cranberry, blackberry, raspberry, black, white or red currant and strawberry. Minor berries include: lingonberry, cloudberry, elderberry, honeyberry, whortleberry, and chokeberry [7]

Mulberry is a rich source of such phytochemicals, in particular anthocyanins and flavonols. Concentrations in berries will be influenced by many factors including environmental conditions, degree of ripeness, cultivar, cultivation site, processing and storage of the fruit [8]

Mulberry is likely due to the presence of polyphenols with known antioxidant and anti-inflammatory effects, such as anthocyanins and/or phenolic acids [9].

Recently, mulberry fruit has been recognized to possess a variety of biological effects sush as antidiabetic, antioxidant, anti-inflammatory and anti-hyper lipidemic activities [1].

Curcumin is a constituent of the rhizome of turmeric (Curcuma longa, Linn) with anti-inflammatory activity Patients in each group showed significant improvement from baseline in morning stiffness, walking time and joint swelling. Although the authors indicate 'convincing evidence of the anti-rheumatic activity of curcumin', no comparisons were reported between the curcumin and phenylbutazone groups [11]

Turmeric, the active constituent of Curcuma longa, L. (family Zingiberaceae), has gained increasing interest because of its anti-cancer, anti-inflammatory, anti-diabetic, and anti-rheumatic properties associated with good tolerability and safety [12].

Turmeric powder is approximately $60-70 \%$ carbohydrates, $6-13 \%$ water, $6-8 \%$ protein, $5-10 \%$ fat, $3-7 \%$ dietary minerals, 3-7\% essential oils, 2$7 \%$ dietary fiber, and 1-6\% curcuminoids, Phytochemical components of turmeric include diarylheptanoids, which occur from numerous curcuminoids, such as curcumin, demethoxycurcumin, and bisdemethoxycurcumin [12]

\section{Patients and Methods}

White mulberry (Morus alba), Black mulberry (Morus nigra) and Curcuim was obtained from local market, Menuofia Governorate, Egypt.
Materials were purchased during the month of April and the experiment was conducted in the period from October-December (2016).

Complete fruend's adjuvant Was obtained from In vivo Gen San Diego, CA 92121-USA. Which were purchased in July 2016.

Rats:

A total of 40 adult normal male albino rats Sprague Dawley strain weighing $140 \pm 10 \mathrm{~g}$ were obtained from Vaccine and Immunity Organization, Ministry of Health, Helwan Farm, Cairo, Egypt.

\section{Biological investigation:}

All biological experiments were done at the Research Institute of Ophthalmology, Medical Analysis Department, Giza, Egypt. All rats were fed on basal diet prepared according to [14] for7 consecutive days. The basal diet was prepared according to [14]. The ingredients of the basal diet (g/100g diet) Casein 12, Sunflower oil 10.0, Mineral mixture 4, Vitamins mixture 1, Fibers (cellulose) 4, Sugar (sucrose) 10, DL-Methionine 0.3, Choline chloride 0.2, Corn star 56.55. Vitamin composition of diets prepared according [15]

\section{Preparation of extraction plant material:}

A commercially available white mulberry (Morus alba), Black (Morus nigra) mulberry fruit and curcium was purchased from local market in Shebin El-Kom governorate. The dried pulp of the fruit (Morus alba), and Black mulberry (Morus nigra) fruit and curcium was ground in apulveriser. The moisture was determined according to the method recommended by [16] using air oven at $100-102^{\circ} \mathrm{C}$ for about 3 hours.

\section{Experimental designs:}

Rats ( $n=40$ rats) were housed in wire cages in a room maintained at $25+2^{\circ} \mathrm{C}$ and kept under normal healthy conditions. Ast group is the healthy rats group not infected by complete fruend's adjuvant and represented the -ve control group and feed on basal diet. Rheumatoid Arthritis was induced in normal healthy male albino rats by intraperitoneal injection of $0.1 \mathrm{ml}$ of complete fruend's adjuvant $\mathrm{mg} / \mathrm{kg}$ body weight according to the method described by [6]. One week after the injection of a complete fruend's adjuvant, fasting blood samples were obtained by retroobital method for estimating fasting. After this adaptation period, rats are divided into 8 groups, each group which consists of 5 rats as follows: Group (1): Rats fed on basal diet as a control negative group (not infected). Group (2): Rats will injected by $0.1 \mathrm{ml}$ of complete fruend's adjuvant and used as a positive control group 
(infected rheumatoid arthritis group). Treated group: Group (3): A group infected rheumatoid arthritis was fed on $5 \%$ of white mulberry powder/Kg diet. Group (4): A group infected rheumatoid arthritis was fed on $10 \%$ of white mulberry powder/Kg diet. Group (5): A group infected rheumatoid arthritis was fed on $5 \%$ of black mulberry powder/Kg diet. Group (6): A group infected rheumatoid arthritis was fed on $10 \%$ of black mulberry powder/Kg diet. Group (7): A group infected rheumatoid arthritis was fed on $5 \%$ of turmeric powder $/ \mathrm{Kg}$ diet. Group (8): A group infected rheumatoid arthritis was fed on $10 \%$ of turmeric powder/Kg diet. The experiment will take 28 days, at the end of the experimental period each rat weight separately then, rats are slaughtered and collect blood samples. Blood samples were centrifuged at (4000 rpm) for ten minute to separate blood serum, then kept in deep freezer till using. Biological evaluations of the different diets were carried out by determination of body weight gain \% (BWG), food efficiency ratio (FIR) according to [17].

\section{Biochemical Analysis:}

laboratory tests:

The erythrocyte sedimentation rate (ESR), Creactive protein, complete blood count (CBC), Rheumatoid factor (RF), Anti-citrullinated protein antibodies (ACPAs).

\section{Statistical analysis:}

The data were analyzed using a completely randomized factorial design [18] when a significant main effect was detected; the means were separated with the Student-Newman-Keuls Test. Differences between treatments of $(p \leq 0.05)$ were considered significant using Costat Program. Biological results were analyzed by one way ANOVA.

\section{Results}

Table (1) represents the effect of feeding white mulberry, black mulberry and turmeric powder on Erythrocyte Sedimentation Rate (ESR) levels on Rheumatoid Arthritis rats. It is clear to note that the negative control ESR was $(11.4 \mathrm{~mm} / \mathrm{hr})$ and positive control ESR was $(28.62 \mathrm{~mm} / \mathrm{hr})$ while the ESR of group (4) increased gradually when compared to positive control, the values were 28.86 $\mathrm{mm} / \mathrm{hr}$. while the values decreased in groups 3,5 , 6,7 and 8 compared with that of control positive, it was $17.92,27.48,22.86,22.54$ and $24.5 \mathrm{~mm} / \mathrm{hr}$, respectively. Treatment with white mulberry, black mulberry and turmeric decreased level of ESR suggest that anti-arthritic activity of white mulberry, black mulberry and turmeric probably mediated by immune-suppressant mechanism treatment with white mulberry, black mulberry and turmeric significantly $(p \leq 0.05)$ reduced serum ESR as compared to arthritic control group [19].

Table (1): Effect of adding white mulberry ,black mulberry and turmeric as powder with different levels on (ESR) Erythrocyte Sedimentation Rate levels on Rheumatoid Arthritis rats.

\begin{tabular}{ll}
\hline Groups & ESR mm/hr \\
\hline Group 1 (Control-) & $11.4 \pm 0.422 \mathbf{f}$ \\
Group 2 (Control+) & $28.62 \pm 0.3962 \mathbf{a}$ \\
Group 3 (5\%) White mulberry & $17.92 \pm 0.683 \mathbf{e}$ \\
Group 4 (10\%) White mulberry & $28.86 \pm 0.6107 \mathbf{a}$ \\
Group 5 (5\%) Black mulberry & $27.48 \pm 0.4147 \mathbf{b}$ \\
Group 6 (10\%) Black mulberry & $22.86 \pm 0.74 \mathbf{d}$ \\
Group 7 (5\%) Turmeric & $22.54 \pm 0.947 \mathbf{d}$ \\
Group 8 (10\%) Turmeric & $24.5 \pm 0.4 \mathbf{c}$ \\
\hline LSD & 0.7829 \\
\hline
\end{tabular}

- Data presented as mean $\pm S E$ ( $n=8$ groups). Significantly different from control and significantly different compared with RA groups using one-way ANOVA followed by the Duncan test.

Table (2) showed the effect of white, black mulberry and turmeric feeding on Rheumatoid factor (RF) levels on Rheumatoid Arthritis rats The mean levels of negative and positive controls presented the mean values were 5.38 and 9.9 IU/L respectively, But the mean values of Group (6) showed 4.58IU/L respectively, which are decreased compared to that of negative control. While the RF of groups $(3,4,5,7$ and 8$)$ increased gradually when compared to negative control, the values were 9.06, 8.2, 8.36, 8.68 IU/L and 8.82IU/L. RF autoantibody such as IgM and IgA are the key pathogenic markers triggered against Fc fragment of IgG and citrullinated peptides in arthritis due to progressive joint destruction [20]. In the present study, treatment in arthritic rats significantly reduced level of serum RF and exhibits anti-arthritic activity probably mediated by suppressing generation of autoantibody towards Fc fragments and protecting cartilage degradation [19].

Table (2): Effect of adding white mulberry, black mulberry and turmeric as powder with different levels on (RF) Rheumatoid factor levels on Rheumatoid arthritis rats.

\begin{tabular}{ll}
\hline Groups & RF (IU/L) \\
\hline Group 1 (Control-) & $5.38 \pm 0.396^{\mathbf{c}}$ \\
Group 2 (Control+) & $9.9 \pm 1.431^{\mathbf{a}}$ \\
Group $3(5 \%)$ White mulberry & $9.06 \pm 0.7536^{\mathbf{b}}$ \\
Group $4(10 \%)$ White mulberry & $8.2 \pm 0.234^{\mathbf{b}}$ \\
Group 5 (5\%) Black mulberry & $8.36 \pm 0.270^{\mathbf{b}}$ \\
Group 6 (10\%) Black mulberry & $4.58 \pm 0.601^{\mathbf{c}}$ \\
Group $7(5 \%)$ Turmeric & $8.68 \pm 0.576^{\mathbf{a b}}$ \\
Group $8(10 \%)$ Turmeric & $8.82 \pm 0.756^{\mathbf{a b}}$ \\
\hline LSD & 0.9299 \\
\hline
\end{tabular}

- Data presented as mean \pm SE ( $n=8$ groups). Significantly different from control and significantly different compared with RA groups using one-way ANOVA followed by the Duncan test. 
Table (3) illustrated the effect of white, black mulberry and turmeric feeding on C-Reactive Protein (CRB) levels on Rheumatoid Arthritis rats negative and positive controls showed scores 4.24 and $12.36 \mathrm{mg} / \mathrm{L}$, r. However groups 3, 4 presented, $6.32 \mathrm{mg} / \mathrm{L}$, respectively, while the lowest value recorded for groups 7,8 presented $4.24 \mathrm{mg} / \mathrm{L}$, with significant difference which are increased compared to the negative control and decreased compared to the positive control. CRP were significantly elevated in the serum of arthritic control group as compared to normal control group CRP in serum was significantly $(p \leq 0.01)$ reduced by treatment [19].

Table (3): Effect of adding white mulberry, black mulberry and turmeric as powder with different levels on (CRB) C-Reactive Protein levels on Rheumatoid Arthritis rats.

\begin{tabular}{ll}
\hline Groups & CRB $(\mathrm{mg} / \mathrm{L})$ \\
\hline Group 1 (Control-) & $4.24 \pm 0.167 \mathbf{c}$ \\
Group 2 (Control+) & $12.36 \pm 0.41 \mathbf{a}$ \\
Group 3 (5\%) White mulberry & $6.32 \pm 0.311 \mathbf{b}$ \\
Group 4 (10\%) White mulberry & $6.32 \pm 0.342 \mathbf{b}$ \\
Group 5 (5\%) Black mulberry & $4.54 \pm 0.7197 \mathbf{c}$ \\
Group 6 (10\%) Black mulberry & $4.4 \pm 0.4949 \mathbf{c}$ \\
Group 7 (5\%) Turmeric & $4.24 \pm 0.4037 \mathbf{c}$ \\
Group 8 (10\%) Turmeric & $4.24 \pm 0.397 \mathbf{c}$ \\
\hline LSD & 0.557 \\
\hline
\end{tabular}

- Data presented as mean \pm SE ( $n=8$ groups). Significantly different from control and significantly different compared with RA groups using one-way ANOVA followed by the Duncan test.

Table (4) represents the effect of white, black mulberry and turmeric feeding on Cyclic citrullinated peptide antibody (Anti-CCP) levels on Rheumatoid arthritis rats. It is clear to note that the control negative was 5.34 and control positive was 24.36, while the (Anti-CCP) of groups 3, 6, 7 and 8 was decreased gradually as compared to positive control the values were $16.32,10.66,9.96$ and $12.16 \mathrm{U} / \mathrm{mL}$ respectively, while the (Anti-CCP) of groups 4 and 5 was increased gradually as compared to positive control, the values were 29.72 and $33.8 \mathrm{U} / \mathrm{ml}$ respectively. In the mouse model, induced higher anti-CCP antibody levels, anticitrullinated protein/peptide antibodies (ACPAs) were reported to be highly specific in the diagnosis of RA [21]. Detection systems for anti-cyclic citrullinated peptide (CCP) antibodies have been improved, and the sensitivity and specificity of anti-CCP antibodies in the diagnosis of RA are 60\%-80\% and $95 \%-98 \%$, respectively [22] . Importantly, anti-CCP antibodies are detected several years before joint inflammation is observed, Due to the high specificity of anti-citrullinated pro- tein/peptide antibodies (ACPAs) in RA, their role in the pathogenesis of RA has become the focus of active investigation [23].

Table (4): Effect of adding white mulberry, black mulberry and turmeric as powder with different levels on (Anti-CCP) Anti-Cyclic citrullinated peptide antibody levels on Rheumatoid Arthritis rats.

\begin{tabular}{ll}
\hline Groups & Anti-CCP $(\mathrm{U} / \mathrm{mL})$ \\
\hline Group 1 (Control-) & $5.34 \pm 0.456 \mathbf{f}$ \\
Group 2 (Control+) & $24.36 \pm 0.415^{\mathbf{c}}$ \\
Group 3 (5\%) White mulberry & $16.32 \pm 0.238 \mathbf{d}$ \\
Group 4 (10\%) White mulberry & $29.72 \pm 0.5403 \mathbf{b}$ \\
Group 5 (5\%) Black mulberry & $33.8 \pm 3.346^{\mathbf{a}}$ \\
Group 6 (10\%) Black mulberry & $10.66 \pm 1.415 \mathbf{e}$ \\
Group 7 (5\%) Turmeric & $9.96 \pm 2.609 \mathbf{e}$ \\
Group 8 (10\%) Turmeric & $12.16 \pm 0.5549 \mathbf{e}$ \\
\hline LSD & 2.089 \\
\hline
\end{tabular}

- Data presented as mean \pm SE ( $n=8$ groups). Significantly different from control and significantly different compared with RA groups using one-way ANOVA followed by the Duncan test.

Table (5) showed the effect of white mulberry, black mulberry and turmeric as powder feeding on Complete Blood Count (CCP) levels on Rheumatoid Arthritis rats. The levels of negative and positive controls hemoglobin were 14.04 and 12.2 $\mathrm{mg} / \mathrm{dl}$, respectively. While the values of groups $3,4,7$ and 8 were $12.82,12.52,13.56$ and $13.02 \mathrm{mg} / \mathrm{dl}$, respectively, which are statistically higher than that of control positive. While the values of groups 5 and 6 were 11.96 and $11.28 \mathrm{mg} / \mathrm{dl}$ which are statistically lower compared to control positive. $\mathrm{Hb}$ increased significantly $(p \leq 0.05)$ in rheumatoid arthritis control treated rats as compared to positive control group indicating a stimulation of immune response towards FCA in arthritic rats [19].

In case of red cell the values of negative and positive control were 4.86 and $4.24 \mathrm{mg} / \mathrm{dl}$, respectively. But the values of all treated except groups 5 and 6 compared to positive control group the mean values were $4.38,4.28 \mathrm{mg} / \mathrm{dl}$. That explains the stimulation of immune response towards FCA in arthritic rats [19].

The values of haematocrit of both negative and positive control were 41.04 and $35.92 \mathrm{mg} / \mathrm{dl}$ respectively. While haematocrit of groups 5 and 6 decreased compared to that of positive control, the values were 35.86 and $35.3 \mathrm{mg} / \mathrm{dl}$ respectively, but haematocrit of groups $3,4,7$ and 8 was higher to positive control. (increase in the hematocrit compared to the positive control. A significant $(p \leq 0.05)$ decrease in mean corpuscular volume was observed in the FCA-treated animals compared with the 
negative control. A significant $(p \leq 0.05)$ increase in mean corpuscular volume (MCV) was observed following methotrexate treatment as compared to positive control [23].

White cell values of negative and positive controls were 10.37 and 4.2 , respectively. WBC decreased in arthritic positive control rats as compared to normal control group indicating a stimu- lation of immune response towards FCA in rheumatoid arthritis rats [19]. While the levels of groups 5 and 6 were 11.274 and $12.67 \mathrm{mg} / \mathrm{dl}$, respectively which are statistically increased compared to that of positive control. Mean WBC count and platelet count significantly $(p \leq 0.05)$ declined in animals treated. A significant improvement in the hematological profile was also observed in rats treated with curcumin [24]

Table (5): Effect of adding white mulberry, black mulberry and turmeric as powder with different levels on (CCP) Complete blood cell levels on Rheumatoid artithrits.

\begin{tabular}{|c|c|c|c|c|}
\hline Groups & $\begin{array}{l}\text { Hemoglobin } \\
(\mathrm{mg} / \mathrm{dl})\end{array}$ & $\begin{array}{l}\text { Red Cell } \\
(\mathrm{mg} / \mathrm{dl})\end{array}$ & $\begin{array}{l}\text { Haematocrit } \\
(\mathrm{mg} / \mathrm{dl})\end{array}$ & $\begin{array}{l}\text { White Cell } \\
(\mathrm{mg} / \mathrm{dl})\end{array}$ \\
\hline Group 1 (Control-) & $14.04 \pm 0.207 \mathbf{a}$ & $4.86 \pm 0.114 \mathbf{a}$ & $41.04 \pm 0.364 \mathbf{a}$ & $10.37 \pm 0.120 \mathbf{b c}$ \\
\hline Group 2 (Control+) & $12.2 \pm 0.316 \mathrm{e}$ & $4.28 \pm 0.178^{\mathbf{b}}$ & $35.92 \pm 0.192^{\mathbf{f}}$ & $4.2 \pm 0.079 \mathrm{e}$ \\
\hline Group 3 (5\%) White mulberry & $12.82 \pm 0.130^{\mathbf{c d}}$ & $4.66 \pm 0.151^{\mathrm{a}}$ & $37.48 \pm 0.207 \mathbf{d}$ & $6.47 \pm 0.120 \mathrm{~d}$ \\
\hline Group $4(10 \%)$ White mulberry & $12.52 \pm 0.1303 \mathrm{~d}$ & $4.62 \pm 0.130^{\mathrm{a}}$ & $37.42 \pm 0.286 \mathbf{e}$ & $8.7 \pm 0.0790^{c}$ \\
\hline Group 5 (5\%) Black mulberry & $11.96 \pm 0.270 \mathrm{e}$ & $4.38 \pm 0.178 \mathbf{b}$ & $35.86 \pm 0.407 \mathbf{f}$ & $11.274 \pm 0.079 \mathbf{a b}$ \\
\hline Group $6(10 \%)$ Black mulberry & $11.28 \pm 0.130 \mathbf{f}$ & $4.24 \pm 0.260^{\mathbf{b}}$ & $35.3 \pm 0.212 \mathrm{~g}$ & $12.67 \pm 0.0836 \mathbf{a}$ \\
\hline Group 7 (5\%) Turmeric & $13.56 \pm 0.3507 \mathbf{b}$ & $4.82 \pm 0.130^{\mathrm{a}}$ & $39.62 \pm 0.319 b$ & $10.22 \pm 0.130 \mathbf{b c}$ \\
\hline Group $8(10 \%)$ Turmeric & $13.02 \pm 0.258^{\mathrm{c}}$ & $4.7 \pm 0.212^{\mathrm{a}}$ & $38.74 \pm 0.16^{\mathrm{c}}$ & $8.19 \pm 3.937 \mathrm{~cd}$ \\
\hline LSD & 0.3079 & 0.226 & 0.3623 & 1.797 \\
\hline
\end{tabular}

- Data presented as mean \pm SE ( $n=8$ groups). Significantly different from control and significantly different compared with RA groups using one-way ANOVA followed by the Duncan test.

\section{Discussion}

RA is a chronic (long-term) disease that causes inflammation sometimes can affect organs as well, for instance, the eyes or lungs [25]

RA is a highly disabling disease of which untreated patients show about $50 \%$ disability in two years and three years of morbidity is $70 \%$ [26].

Mulberry fruits are rich in phenolic compounds, including flavonols and phenolic acids, as well as anthocyanins, particularly in the case of dark fruits, The total phenolic contain in fruits ranged from 7.7 to $11.2 \mathrm{mg} \mathrm{GAE} / \mathrm{g} \mathrm{dw}$, and flavonols from 0.07 to $0.51 \mathrm{mg} / \mathrm{g} \mathrm{dw}$. Moreover, the high amount of alkaloids $(660 \mathrm{mg} / 100 \mathrm{~g})$ was found in fresh fruits The antioxidant capacity of dark fruits is significant, while mean values ranged from $3.84 \mathrm{mg}$ Trolox $/ \mathrm{g}$ $\mathrm{dw}$ to $20.73 \mathrm{mg}$ Trolox/g dw for ABTS and from $3.62 \mathrm{mg}$ Trolox/g dw to $12.91 \mathrm{mg}$ Trolox/g dw [27]

Morus nigra contain high levels of anthocyanins, which give black raspberries their rich, dark color. Anthocyanins work as antioxidants to help fight free radical damage in the body. The anthocyanin level of black raspberries is $214-589 \mathrm{mg} / 100 \mathrm{~g}$ [28]
The Morus nigra fruits contain rich flavonoids and two kinds of anthocyanins (C3G and C3R). TF may be a multi-target-directed drug with antiinflammatory and anti-nociceptive effects. These effects might correlate to its inhibitory activities of pro-inflammatory cytokines. TF is non-cytotoxic at relevant concentrations. These findings suggest that the black mulberry fruits are a valuable source of flavonoids and a natural antioxidant with no toxic side effects. Thus, the fruits are an alternative treatment for inflammatory and nociceptive diseases [29].

Increasing evidence suggests that berry fruit consumption has a significant potential in the prevention and treatment of most risk factors associated with metabolic syndrome and its cardiovascular complications in the human population. This is likely due to the presence of polyphenols with known antioxidant and anti-inflammatory effects, such as anthocyanins and/or phenolic acids [8]

Curcumin was compared to phenylbutazone in patients with rheumatoid arthritis. Curcumin was given at $1200 \mathrm{mg}$ daily was effective in improving joint swelling, morning stiffness, and walking time. 
Although phenylbutazone provided an even greater benefit dosages [13].

This current study showed that the best result were in group $7,8(5 \%, 10 \%)$ Turmeric which indicated no sign of regression of damaged joints, followed by $10 \%$ black mulberry (group 6) then $5 \%$ black mulberry (group 5) which showed improvement reaching up to $90 \%, 85 \%$ respectively, while $10 \%$ white mulberry showed slight improvement about $65 \%$ then $5 \%$ white mulberry that showed improvement $45 \%$. These results agree with [19] .

Turmeric powder is approximately $1-6 \%$ curcuminoids, Phytochemical components of turmeric include diarylheptanoids, which occur from numerous curcuminoids, such as curcumin, demethoxycurcumin, and bisdemethoxycurcumin [13] .

According to a study published in the "Journal of Medicinal Food", mulberry is an excellent source of $\mathrm{C} 3 \mathrm{G}$, traditionally used for treating inflammatory conditions such as rheumatoid arthritis. During this animal research, mulberry fruit extract provided anti-inflammatory benefits for arthritic rats [30].

\section{Conclusion:}

We have shown that: Rats injected by $0.1 \mathrm{ml}$ of complete fruend's adjuvant and used as a positive control group produced a definite edema within a few hours with progressive arthritis by the 9 th day after inoculation. All the treatments were initiated from the 10 th day and continued till the 45 th day [24].

And Elevation in the levels of ESR, CRB, Ant$\mathrm{CCP}, \mathrm{RF}, \mathrm{CCB}$, In addition, RA treatment with white mulberry, black mulberry and turmeric as powder induced significant in (ESR) Erythrocyte Sedimentation Rate, (RF) Rheumatoid factor, (CRB) C-Reactive Protein, (Anti-CCP) Anti-Cyclic citrullinated peptide antibody, (CCP) Complete blood cell the best result were in groups $(7,8)$. Followed by group (6) compared with group (2). The study recommends the tested medicinal plants are useful for healing as well as for curing of human diseases because of the presence of phytochemical constituents.

\section{Recommendations:}

1- The results showed that the use of black berries and turmeric has a markedly significantly effect for reducing the incidence of rheumatoid symptoms as appeared in 2-X-ray photo which showed that black berries and turmeric powder.
2- So we recommended using them in different forms, whether in food or drinks to delay or reduce the incidence of rheumatoid risk.

3- We also recommended using black berries and turmeric with pharmacotherapy to increase the delay incidence of rheumatoid risk.

4- Use The Mediterranean-type diet is characterized by less red meat and more fish, in add-ition to an abundance of plant food (fruits, vegetables, wholegrain cereals, nuts, and legu-mes), olive oil as the principal source of fat.

\section{References}

1- KOBAK S.: Demographic, clinical and serological features of Turkish patients with rheumatoid arthritis: Evaluation of 165 patients. Clin. Rheumatol., 30: 843-847, 2011.

2- MODY G.M.: Rheumatoid arthritis and connective tissue disorders: SubSaharan Africa. Baillieres Clinical Rheumatology, 9: 31-44, 1995.

3- ARNETT F.C., EDWORTHY S.M., BLOCH D.A., MCSHANE D.J., FRIES J.F. and COOPER N.S.: The American Rheumatism Association 1987 revised criteria for the classify-cation of rheumatoid arthritis. Arthritis Rheum., 31 (3): 315-324, 1988.

4- NIEWOLD T.B., HARRISON M.J. and PAGET S.A.: Anti-CCPantibody testing as a diagnostic and prognostic tool in rheumatoid arthritis. Q. J. Med., 100: 193-201, 2007.

5- IBANEZ DE CACERES I.I., VILLANUA M., SOTO L., MARTIN I. and LOPEZ-CALDERON A.: IGF-I and IGFI-binding proteins in rats with adjuvant-induced arthritis given recombinant human growth hormone. J. Endocrinol., 165: 537-540, 2000.

6- LAIMA L., EIVA B., RUTA, B., DALIA V., ELVYRA R. and VYTAUTAS A.: Antiarthritic and hepatoprotective effect of derinat on adjuvant arthritis in rats. Acta. Med. Lituanica., 13: 236-344, 2006.

7- NILE S.H. and PARK S.W.: Edible berries: Bioactive components and their effect on human health. Nutrition, 30: 134-144, 2014.

8- HÄKKINEN S.H., KÄRENLAMPI S.O., MYKKÄNEN, H.M. and TÖRRÖNEN A.R.: Influence of domestic processing and storage on flavonol contents in berries. J. Agric. Food. Chem., 48: 2960-2965, 2000.

9- STEFANO V., CRISTIAN D.B., SALVATORE C., PATRIZIA R. and DOROTHY K.Z.: Berry Fruit Consumptio and Metabolic Syndrome, Antioxidants, 5: 34 MDPI, 2016.

10- KIM S.Y., PARK K.J. and LEE W.C.: Anti-inflammatory and antioxidative effects of Morus spp. fruit extract. Kor. J. Med .Cop. Sci., 6: 204 -209, 1998.

11- DEODHAR S.D., SETHI R. and SRIMAL R.C.: Preliminary study on antirheumatic activity of curcumin (diferuloyl methane). Indian J. Med. Res., 71: 632-634, 1980.

12- JAN FRANK, CHRISTINA SCHIBORR, ALEXA KOCHER, JÜRGEN MEINS, DARIUSH BEHNAM, MANFRED SCHUBERT-ZSILAVECZ and MONA ABDEL- 
TAWAB: Transepithelial Transport of Curcumin in Caco2 Cells Is significantly Enhanced by Micellar Solubilisation, Plant Foods Hum. Nutr., 72: 48-53, 2017.

13- NELSON K.M., DAHLIN J.L. and BISSON J.: The Essential Medicinal Chemistry of Curcumin: Miniperspective. Journal of Medicinal Chemistry, 60 (5): 16201637, 2017.

14- AIN: American Institute of Nutrition Purified Diet for Laboratory Rodent, Final report. J. Nutrition, 123: 19391951, and O. Compactum Benth, J. Essential. Oil. Res., 8 (6): 657-664, 1993.

15- A.O.A.C.: Official Methods of Analysis, Association of Official Analytical Chemists, 18 th Ed., Washingtion, D.C., ISA, 2005.

16- A.O.A.C.: Official Methods of the Association of Official Analytical Chemists. 15 th Ed., AOAC 2200 Wilson Boulevard Arling, Virginia, 22201, U.S. A., 2010.

17- CHAPMAN D.G., CASTILLA R. and CAMPBELL J. A.: Evaluation of protein in food. Determination of protein and feed efficiency ratio. Can. J. Biochem. and Physiol. 679-686, 1959, 1959.

18- SAS: SAS users Guide: Statistics Version 5 th Ed., SAS. Institute Inc., Cary N.C, 1988.

19- GATE S., BANDAWANE D.S., BEAUTIKUMARI S and PATEL A.: Tannin Rich Fraction of Punica granatum Linn. Leaves Ameliorates Freund's Adjuvant Induced Arthritis in Experimental Animals, Pharmacologia, 5: 1931, 2014.

20- VAN DER LINDEN M.P., FEITSMA A.L., le CESSIE S KERN M. and OLSSON L.M.: Association of a singlenucleotide polymorphism in CD40 with the rate of joint destruction in rheumatoid arthritis. Arthritis Rheumatism, 60: 2242-2247, 2009.

21- GIRBAL N.E., DURIEUX J.J., ARNAUD M., DALBON P., SEBBAG M., VINCENT C., SIMON M., SENSHU, T., MASSON B.C., JOLIVET R.C., JOLIVET M. and SERRE G.: The epitopes targeted by the rheumatoid arthritis-associated antifilaggrin autoantibodies are posttranslationally generated on various sites of (pro) filaggrin by deimination of arginine residues. J. Immunol., 162: 585-594, 1999.
22- DAMJANOVSKA L., THABET M.M., LEVARTH E.W., STOEKEN R.G., VOORT E.I., TOES R.E., HUIZINGA T.W., HELM V. and MIL A.H.: Diagnostic value of antiMCV antibodies in differentiating early inflammatory arthritis. Ann. Rheum. Dis., 69: 730-732, 2010.

23- NIELEN M.M., VAN S.D., REESINK H.W., STADT R.J., HORST B.I.E., KONING M.H., HABIBUW M.R VANDENBROUCKE J.P. and DIJKMANS B.A.: Specific autoantibodies precede the symptoms of rheumatoid arthritis: A study of serial measurements in blood donors. Arthritis Rheum., 50: 380-386, 2004.

24- DAVID BANJI, JYOTHI PINNAPUREDDY, OTILIA BANJI J.F., RANJITH KUMAR A. and NARSI REDDY K.: Evaluation of the concomitant use of methotrexate and curcumin on Freund's complete adjuvant-induced arthritis and hematological indices in rats, Indian. $\mathbf{J}$. Pharmacol., Sep-Oct., 43 (5): 546-550, 2011.

25- ERIC RUDERMAN M.D. and SIDDHARTH TAMBAR, M.D.: American College of Rheumatology. Grohwell. Pub., London, p. 128, 2012.

26- YANJUN KONG, QIANDE ZHANG and MUXIN WEI1: Can New Diagnostic Criteria of Rheumatoid Arthritis Really Do An Early Diagnosis? A Case Report of Early Diagnosis and treatment of rheumatoid arthritis with traditional medicine, Ann. Orthop. Rheumatol., 2 (2): 1019-1021, 2014

27- SÁNCHEZ-SALCEDO E.M., MENA P., GARCÍA-VIGUERA C., MARTÍNEZ J.J. and HERNÁNDEZ F.: Phytochemical Evaluation of White (Morus alba L.) and Black (Morus nigra L.) Mulberry Fruits: A Starting Point for the Assessment of Their Beneficial Properties". Journal of Functional. Foods, 12: 399-408, 2015.

28- DHARMANANDA S.: Fruit as medicne, Morus Fruit (Mulberry). Institute for Traditional Medicine, Portland, Oregon., 2003.

29- CHEN H., PU J., LIU D., YU W., SHAO Y. and YANG G.: Anti-Inflammatory and Antinociceptive Properties of Flavonoids from the Fruits of Black Mulberry (Morus nigra L.). PLoS. One, 11 (4), 2016.

30- YANG X.Y., PARK G.S., LEE M.H.; CHANG, I.A., KIM, Y.C. and KIM S.Y.: Toll-like receptor 4-mediated immunoregulation by the aqueous extract of Mori Fructus. Phytother. Res., 23: 1713-20, 2009. 


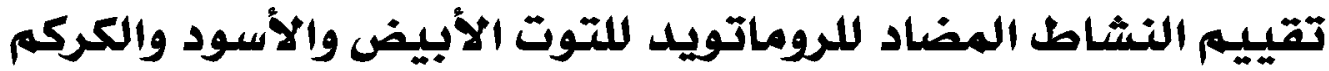

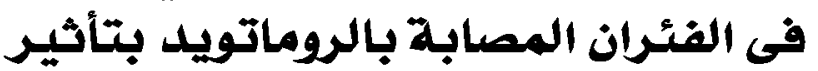

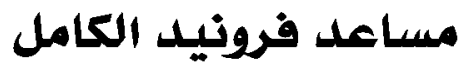

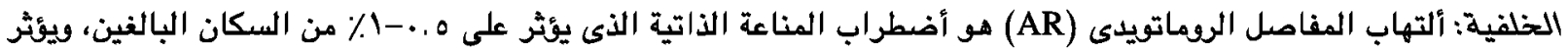

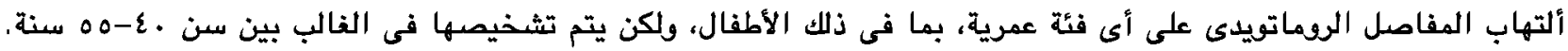

الهدف: من هذه الدراسة هو تقييم النشاط المضاد للروماتويد للتوت الأبيض والأسود والكركم وذلك فى الفتران المصابة بإستخدام

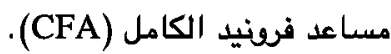

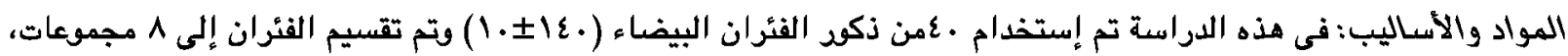

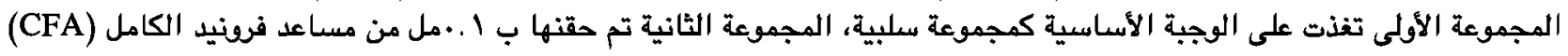

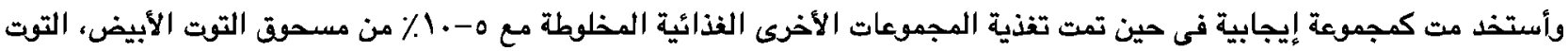

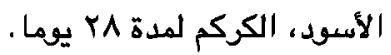

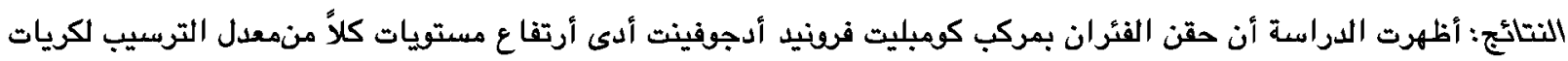

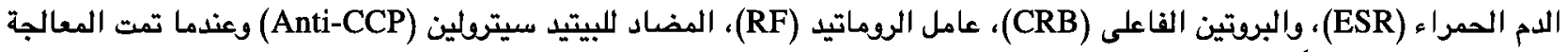

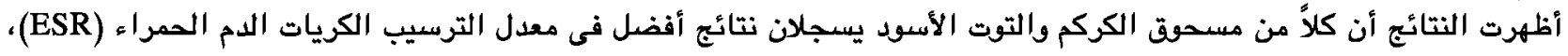

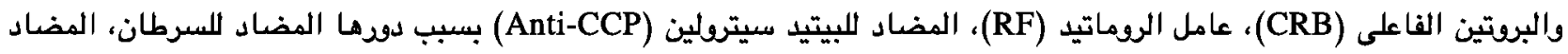
اللالتهابات، والمضاد اللسكر، والخصائص المضادة اللورماتزم.

الخلاصة: توصى الدراسة بأستخدام النباتات الطبية لأنها مفيدة للشفاء وكذلك لعلاج الأمراض البشرية بسبب وجود المكونات 